Kumawula, Vol. 4, No.1, April 2021, Hal 49 - 58

DOI: https://doi.org/10.24198/kumawula.v4i1.30658

ISSN 2620-844X (online)

Tersedia online di http://jurnal.unpad.ac.id/kumawula/index

\title{
SOSIALISASI PEMELIHARAAN PERSONAL HYGIENE DAN PROTEKSI DIRI DI LINGKUNGAN PERUMAHAN PADA ERA NEW NORMAL
}

\author{
1*Nina Karlina, $^{2}$ Budiman Rusli, ${ }^{3}$ Entang Adhi Muhtar, ${ }^{4}$ Candradewini \\ ${ }^{1}$ Administrasi Publik, Fakultas Ilmu Sosial dan Ilmu Politik Universitas Padjadjaran \\ ${ }^{2}$ Administrasi Publik, Fakultas Ilmu Sosial dan Ilmu Politik Universitas Padjadjaran \\ ${ }^{3}$ Administrasi Publik, Fakultas Ilmu Sosial dan Ilmu Politik Universitas Padjadjaran \\ ${ }^{4}$ Administrasi Publik, Fakultas Ilmu Sosial dan Ilmu Politik Universitas Padjadjaran
}

*Korespondensi : nina.karlina@unpad.ac.id

\begin{abstract}
Residential housing is a group of houses that have a function as an occupancy or residence environment that has various environmental infrastructures such as drinking water supply, garbage disposal, electricity, telephone, roads and environmental facilities which are supporting facilities that function for the organization and development of life. During the Covid-19 pandemic, they were required to protect themselves and the environment in order to cope with the spread of Covid-19. One of the solutions was by arranging residential and housing areas. In the new normal era, this is very important because many people have the perception that this new normal has returned to its usual situation before this pandemic. However, the spread of Covid-19 is still quite high per day, which is around 3000 new cases in Indonesia. In tackling the spread of the coronavirus, namely complying with health protocols in daily activities, such as wearing masks, maintaining distance, avoiding crowds and always washing hands. This can be said to be a very important way of personal hygiene and self-protection, if people can comply with health protocols to maintain personal hygiene and self-protection, it can reduce the spread of the coronavirus in living environments such as settlements and housing. There must be awareness from each citizen to create a residential environment where they live that is free from the spread of the coronavirus.

Keyword: Settlements, Housing, Personal hygiene, Personal Protection, Covid-19.
\end{abstract}

Keywords : Settlements, Housing, Personal hygiene, Personal Protection, Covid-19.

\begin{abstract}
ABSTRAK
Perumahan merupakan kelompok rumah yang memiliki fungsi sebagai lingkungan tempat tinggal maupun hunian yang memiliki berbagai prasarana lingkungan seperti kelengkapan dasar meliputi penyediaan air minum, pembuangan sampah, listrik, telepon, jalan serta sarana lingkungan yang merupakan sarana penunjang yang berfungsi untuk penyelenggaraan serta pengembangan kehidupan. Pada masa pandemi Covid-19 ini dituntut untuk menjaga diri dan lingkungan agar dapat menanggulangi penyebaran Covid-19. Salah satu dengan melakukan penataan kawasan pemukiman dan perumahan. Pada era new normal ini sangatlah penting karena banyak masyarakat berpersepsi bahwa new normal ini kembali ke situasi biasa sebelum adanya pandemi ini. Akan tetapi penyebaran Covid-19 masih cukup tinggi per harinya yaitu sekitar 3000 kasus baru terjadi di Indonesia. Dalam menanggulangi penyebaran virus corona yaitu mematuhi protokol kesehatan dalam beraktivitas sehari-hari misalnya penggunaan masker, menjaga jarak, hindari kerumunan serta selalu mencuci tangan. Hal tersebut dapat dikatakan sebagai cara personal hygiene dan proteksi diri yang sangat penting, apabila masyarakat sudah dapat mematuhi protokol kesehatan untuk memelihara personal hygiene dan proteksi diri maka bisa mengurangi penyebaran virus corona di lingkungan tempat tinggal seperti pemukiman dan perumahan. Harus adanya kesadaran dari masing-masing warga menciptakan lingkungan perumahan tempat tinggalnya terbebas dari penyebaran virus corona
\end{abstract}

Kata kunci: Pemukiman, Perumahan, Personal hygiene, Proteksi Diri, Covid-19. 


\section{PENDAHULUAN}

Di era pandemi saat ini, tentu peran dari Personal Hygiene dapat membantu dalam upaya pencegahan (preventif) di masa pandemi Covid-19 yang sedang mewabah. World Health Organization (WHO) sendiri telah memberikan arahan bagi masyarakat untuk mengurangi paparan dan transmisi penyakit atau infeksi melalui personal hygiene (kebersihan diri), yaitu kebersihan tangan dan saluran pernapasan serta keamanan pangan. Personal hygiene perlu diperhatikan pada musim pandemi Covid-19. Personal hygiene ini merupakan penerapan pola hidup bersih dan sehat yang ditujukan pada diri sendiri sehingga dapat menjaga kebersihan diri/meningkatkan kekebalan daya tahan tubuh terhadap virus dan bakteri di masa pandemi Covid-19 saat ini.

Peran individu dalam menyikapi pandemi Covid-19 adalah sangat penting, individu diharapkan disiplin dalam melindungi diri sendiri dan orang lain dengan melaksanakan protokol kesehatan pencegahan Covid-19 dan melakukan personal hygiene (kebersihan diri) sebagai salah satu upaya preventif. Personal hygiene menjadi penting karena personal hygiene yang baik akan meminimalkan pintu masuk (portal of entry) mikroorganisme yang ada di mana-mana dan pada akhirnya mencegah seseorang terkena penyakit (Saryono, 2010).

Menurut Tarwoto (2010) personal hygiene adalah suatu tindakan untuk memelihara kebersihan dan kesehatan seseorang untuk kesejahteraan fisik dan psikis. Pemenuhan personal hygiene diperlukan untuk kenyamanan individu, keamanan, dan kesehatan. Kebutuhan personal hygiene ini diperlukan baik pada orang sehat maupun pada orang sakit. Praktik personal hygiene bertujuan untuk peningkatan kesehatan dimana kulit merupakan garis tubuh pertama dari pertahanan melawan infeksi Dengan implementasi tindakan hygiene pasien atau membantu anggota keluarga untuk melakukan tindakan itu maka akan menambah tingkat kesembuhan pasien (Potter \& Perry, 2005). Personal hygiene (kebersihan diri) merupakan perawatan diri yang dilakukan untuk memelihara kebersihan dan kesehatan diri sendiri baik secara fisik maupun mental. Tingkat kebersihan diri seseorang umumnya dilihat dari penampilan yang bersih dan rapi serta upaya yang dilakukan seseorang untuk menjaga kebersihan dan kerapihan tubuhnya setiap hari (Saputra, 2013)

Pengelolaan hygiene penting karena erat kaitannya dengan bagaiamana penyakit berbahaya bisa bisa timbul dan ditularkan dari makanan, orang, maupun sebuah tempat atau benda lain (Satyarini, Pratikna, Mulia, \& Dewi, 2020). Personal hygiene yang tidak baik akan mempermudah tubuh terserang berbagai penyakit, seperti penyakit skabies, penyakit infeksi, dan penyakit saluran cerna atau bahkan dapat menghilangkan fungsi bagian tubuh tertentu seperti halnya kulit (Sudarto, 1996). Kebersihan diri yang baik merupakan salah satu cara paling efektif untuk melindungi diri kita dan orang lain dari penyakit, seperti gastroenteritis. Salah satu upaya kita untuk mencegah dan menghindarkan diri dari Covid19 yang saat ini telah menyebar adalah dengan menjaga personal hygiene dengan baik, yaitu dengan cara:

1. Menjaga kebersihan diri, seperti pakaian rumah \& lingkungan.

2. Membiasakan mencuci tangan dengan sabun dan air yang mengalir.

3. Menjaga pola makan yang sehat dengan gizi seimbang $\&$ bebas dari bibit penyakit.

4. Menjaga imunitas tubuh \& kesehatan jasmani.

5. Menutup mulut dan hidung dengan memakai masker ketika berada di luar rumah/tempat umum.

6. Menjaga jarak (physical distancing) ketika berpergian.

7. Membuang sampah pada tempatnya.

8. Perbanyak konsumsi air putih.

9. Menjaga kebersihan anggota tubuh (tangan, rambut, kaki, kulit, gigi, kuku, mata, telinga).

Dengan upaya tersebut yang dapat dilakukan, dan menjadikan kebiasaan kita sehari-hari merupakan tujuan kita bersama untuk mencegah timbulnya penyakit pada diri sendiri maupun orang 
Di akhir tahun 2019, muncul berita yang menggemparkan dunia yakni tentang ditemukannya virus corona baru yakni SARSCoV-2 di Wuhan, Cina (Lawrenche et al., 2020). Dan pada awal tahun 2020 ini, WHO mendeklarasikan kondisi pandemi di seluruh dunia dampak eskalasi Coronavirus Disease 2019 (Covid-19) yang menyerang 213 negara dan teritori. Per Juli 2020, kasus positif mencapai lebih dari 16 juta orang dengan lebih dari 650 ribu kematian di seluruh dunia. Di Indonesia sendiri, kasus positif sudah melewati angka 100 ribu dengan kematian di angka 4838. Kondisi ini secara signifikan memberikan dampak yang sangat besar di masyarakat. Pemerintah memberlakukan Pembatasan Sosial Berskala Besar (PSBB) di banyak kota besar di Indonesia. Hal ini adalah salah satu upaya pemerintah untuk menekan angka penularan virus corona sambil menyosialisasikan protokol-protokol kesehatan yang perlu ditaati oleh masyarakat, yaitu penggunaan masker, cuci tangan menggunakan sabun dan air mengalir, menerapkan physical distancing minimal 1.5-2 meter, dan menjaga pola hidup yang sehat. Berakhirnya PSBB ini melahirkan istilah baru di masyarakat yang disebut new normal. Definisi new normal yang cenderung multitafsir menimbulkan kebingungan di masyarakat. Bagi sebagian orang, era new normal ini dianggap sebagai berakhirnya pandemi Covid-19 sehingga beranggapan protokol kesehatan dapat dilonggarkan. Hal ini tentunya yang mengakibatkan semakin tingginya angka kasus positif Covid-19 di era new normal ini.

Virus corona dapat menular secara cepat dan mudah melalui droplet yang keluar saat bersin dan batuk. Droplet yang terinfeksi virus corona ini dapat masuk melalui mulut, hidung, dan mata. Virus ini bisa menghasilkan gejala batuk, demam, dan sesak napas pada orang yang terinfeksi. Namun, beberapa orang yang terkonfirmasi positif Covid-19 tidak menunjukkan gejala apapun. Kasus ini disebut OTG atau orang tanpa gejala. Orang-orang ini sangat berisiko menularkan virus ini secara masif tanpa disadari. Hal ini menjadi penyumbang kasus positif terbanyak yang membentuk klaster besar di suatu daerah. Sebelum dikonfirmasi positif, orang-orang tanpa gejala ini beraktivitas secara normal di masyarakat, baik itu bekerja, berbelanja, dan menggunakan moda transportasi umum dan ruang publik lainnya. Secara tidak sadar, mereka menularkan virus ini ke orang lain saat berbicara, makan, atau berjabat tangan. Individu-individu lain yang melakukan kontak dengan orang tanpa gejala (OTG) tersebut akan melakukan kontak lain dengan orang-orang disekitarnya. Hal ini meningkatkan kemungkinan munculnya rantai infeksi yang panjang dari satu OTG tersebut. Orang-orang terdekat di lingkungan keluarga, seperti orang tua, adik, kakak, istri/suami, anak, dan tetangga sangat berisiko terinfeksi virus ini. Dari lingkungan keluarga, infeksi ini dapat meluas ke lingkungan perumahan sehingga mampu membentuk klaster besar Covid-19 ini.

Dari fenomena permasalahan tersebut, lingkungan perumahan perlu diberikan perhatian khusus sebagai upaya dalam membatasi penularan Covid-19 di lingkup yang lebih kecil sehingga tidak sampai berdampak ke lingkup yang lebih besar. Mahasiswa merasa lingkungan perumahan dengan pemeliharaan yang baik, protokol yang ditegakkan, dan warga yang koordinatif dan kontributif tentunya dapat mencegah penularan virus corona. Dari hasil penilaian di masing-masing lingkungan perumahan mahasiswa, ada beberapa permasalahan yang timbul. Salah satunya adalah kurangnya kesadaran warga perumahan mengenai pentingnya menaati protokolprotokol kesehatan. Bapak-bapak masih banyak yang tidak menggunakan masker dan tidak mencuci tangan saat masuk masjid untuk melakukan sholat jumat dan sholat berjamaah. Ibu-ibu yang tidak menerapkan physical distancing dengan berkumpul saat berbelanja sayur dan pengajian atau arisan. Dan terakhir ada anak-anak dan remaja di lingkungan perumahan yang berkumpul, bermain, dan berolahraga tanpa memperhatikan protokol kesehatan yang benar.

Mahasiswa dan pembimbing merasa fenomena di atas perlu dijadikan fokus kegiatan KKN-PPM Virtual dengan tujuan untuk 
meningkatkan kesadaran dan pengetahuan warga perumahan mengenai bahaya dan risiko tertular Covid-19 di lingkungan perumahan dengan memberikan sosialisasi mengenai pemeliharaan personal hygiene dan proteksi diri. Sosialisasi ini dilakukan secara daring untuk meminimalisasi kumpulan massa. Namun dengan pertimbangan, sosialisasi daring ini dapat diakses oleh subjek sasaran dan diselenggarakan pada hari dan waktu yang dapat memaksimalkan partisipasi subjek sasaran tersebut.

\section{METODE}

Kegiatan pengabdian ini dilakukan pada

1. Ibu-ibu pengajian, Perumahan Bekasi Timur Permai (BTP)

2. Ikatan Remaja Masjid, Gegesik Cirebon

3. Bapak RW RT, Satpam, Karang Taruna di Perumahan Cijati Asri Kabupaten Garut

4. Karang Taruna di Perumahan Prima Lingkar Asri, Jatibening Bekasi

5. Warga lingkungan Perumahan, Margahayu Raya Sekejati Buah Batu Bandung

6. Karang Taruna Komplek Margahayu Raya Sekejati Kec. Buah Batu Bandung

Adapun langkah langkah pengabdian adalah;

1. Analisis situasi masyarakat

Kegiatan analisis situasi masyarakat bertujuan untuk memahami masalah yang dihadapi oleh masyarakat di daerah perumahan. Dalam pengabdian ini, kegiatan analisis situasi masyarakat berupa identifikasi permasalahan2 yang dihadapi masyarakat di perumahan di masa new normal. Metode yang digunakan adalah melalui observasi dan wawancara dengan ibuibu pengajian, ikatan remaja masjid, karang taruna dan masyarakat di perumahan. Pada masa pandemi Covid-19, observasi dan wawancara dilakukan dengan bantuan teknologi komunikasi (melalui Whatsapp) dan juga mengunjungi perumahan, masjid, dan karang taruna secara langsung dengan memperhatikan protokol kesehatan.

2. Merancang kegiatan pengabdian

Kegiatan pengabdian dirancang sesuai dengan masalah yang dihadapi di lapangan dengan mempertimbangkan kondisi masyarakat dengan tetap memerhatikan kondisi pada saat pandemi Covid-19. Hasil analisis situasi masyarakat menunjukkan bahwa pengabdian dilakukan 6 (enam) subjek yang akan diwawancara dan di observasi, yaitu ibu-ibu pengajian dari Perumahan Bekasi Timur Permai (BTP), Ikatan Remaja Masjid, Gegesik Cirebon, bapak RW RT, satpam, Karang Taruna dari Perumahan Cijati Asri Kabupaten Garut, Karang Taruna di Perumahan Prima Lingkar Asri, Jatibening Bekasi, warga lingkungan perumahan, Margahayu Raya Sekejati Buah Batu Bandung, dan Karang Taruna Komplek Margahayu Raya Sekejati Kec. Buah Batu Bandung. Proses Sosialisasi Pemeliharaan Personal Hygiene dan Proteksi Diri di Lingkungan Perumahan pada Era New Normal tidak dapat dilaksanakan secara langsung, maka webinar, pembuatan video, dan Instagram merupakan alternatif kegiatan dalam pengabdian ini.

3. Pelaksanaan kegiatan

Metode yang digunakan dalam pengabdian ini adalah pendidikan kepada masyarakat. Pendidikan masyarakat ini bertujuan untuk mengenalkan pemeliharaan personal hygiene dan proteksi diri di lingkungan perumahan di era New Normal. Berdasarkan analisis situasi sebelumnya, maka kegiatan lebih banyak dilaksanakan secara langsung (tidak secara daring), yaitu dengan cara mendatangi masyarakat dan pelaku 
usaha di perumahan, pengajian, karang taruna membagikan poster berbagai tempat, juga pembuatan video dan akun Instagram serta webinar.

4. Evaluasi kegiatan

Evaluasi kegiatan dilakukan untuk mengetahui apakah pelaksanaan pemeliharaan personal hygiene dan proteksi diri sesuai dengan harapan dan tujuan dari pengabdian ini. Bentuk evaluasi adalah dengan cara observasi dan wawancara

\section{HASIL DAN PEMBAHASAN}

Secara garis besar terdapat dua kegiatan utama yaitu identifikasi situasi lokasi pengabdian dalam pemeliharaan personal hygiene dan proteksi diri dan kegiatan sosialisasi pemeliharaan personal hygiene dan proteksi diri.

1. Hasil identifikasi situasi perumahan dalam pemeliharaan personal hygiene dan proteksi diri

Dari hasil diskusi yang telah dilakukan, dapat disimpulkan bahwa fokus sasaran di masing-masing wilayah tujuan pengabdian cenderung sudah paham tentang bagaimana dasar-dasar tentang memelihara kesehatan secara personal seperti menggunakan masker, physical distancing, mencuci tangan, protokol masuk rumah dan pola hidup sehat. Di mana memang dalam masing-masing wilayah mahasiswa, telah menerapkan protokol kesehatan yang diberlakukan oleh RT/RW di komplek perumahan wilayahnya. Selain itu, penerapan protokol kesehatan di masing-masing wilayah peserta KKN pun memasang beberapa peraturan, seperti penggunaan masker, pengecekan suhu dan juga fasilitas untuk mencuci tangan.

Dengan diadakannya program pengabdian ini mengenai "Pemeliharaan Personal Hygiene dan Proteksi Diri di Lingkungan Perumahan pada Era New Normal" yang diselenggarakan di masing- masing lingkungan mahasiswa dengan mengadakan sosialisasi berupa webinar, diharapkan dapat mengedukasi setiap masyarakat yang ada di masing-masing wilayah agar lebih sadar akan pentingnya menjaga dan memelihara kesehatan secara persona karena sejatinya kesehatan fisik bagi setiap masyarakat sangatlah penting untuk terus selalu diperhatikan, agar dikemudian hari tidak terjadi hal-hal yang tidak diinginkan akibat ketidaksadaran tiap individu tentang pentingnya memelihara kesehatan terlebih di masa pandemi ini.

Kegiatan pengenalan personal hygiene dan proteksi diri di lingkungan perumahan pada era new normal

Terdapat tiga kegiatan dalam pengenalan bahasa asing yaitu: pembagian poster, pembuatan video/akun Instagram dan webinar.

1) Pembagian poster

- Poster merupakan media yang diharapkan mampu memotivasi tingkah laku orang yang melihatnya. Poster menjadi media komunikasi yang efektif untuk menyampaikan pesan singkat, padat, dan impresif karena ukuran yang relatif besar. Dalam buku The Poster: Art, Advertising Design, and Collecting (2014) karya Ruth Iskin, pengertian poster adalah media gambar yang memiliki sifat persuasif tinggi. Hal tersebut karena poster menampilkan suatu persoalan atau tema yang menimbulkan perasaan kuat terhadap publik.

- Sasaran/subjek kegiatan, di antaranya:

1. Ibu-ibu pengajian, Perumahan Bekasi Timur Permai (BTP)

2. Ikatan Remaja Masjid, Gegesik Cirebon

3. Bapak RW RT, Satpam, Karang Taruna di Perumahan Cijati Asri Kabupaten Garut 
4. Karang Taruna di Perumahan Prima Lingkar Asri, Jatibening Bekasi

5. Warga lingkungan Perumahan, Margahayu Raya Sekejati Buah Batu Bandung

6. Karang Taruna Komplek Margahayu Raya Sekejati Kec. Buah Batu Bandung Adapun poster2 yang dibuat adalah sebagai berikut:

2. Webinar "Pemeliharaan Personal hygiene dan Proteksi Diri di Lingkungan Perumahan pada Era New Normal"

Kegiatan ini dilaksanakan secara virtual dengan menggunakan media komunikasi online yaitu google meet. Tujuan dari kegiatan ini yaitu untuk meningkatkan pengetahuan masyarakat terhadap pemeliharaan personal hygiene

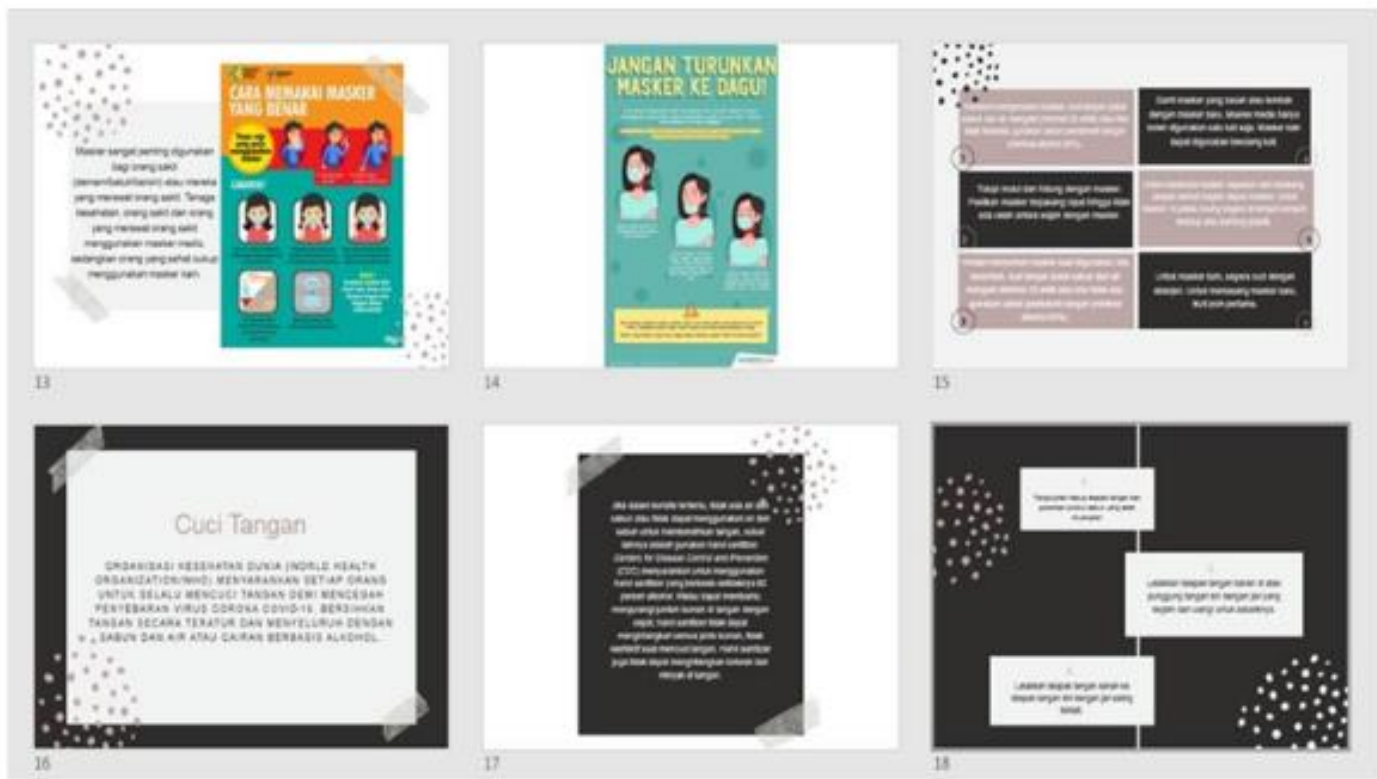

Gambar 1. Poster Pengenalan Personal Di Lingkungan Perumahan pada Era New Normal

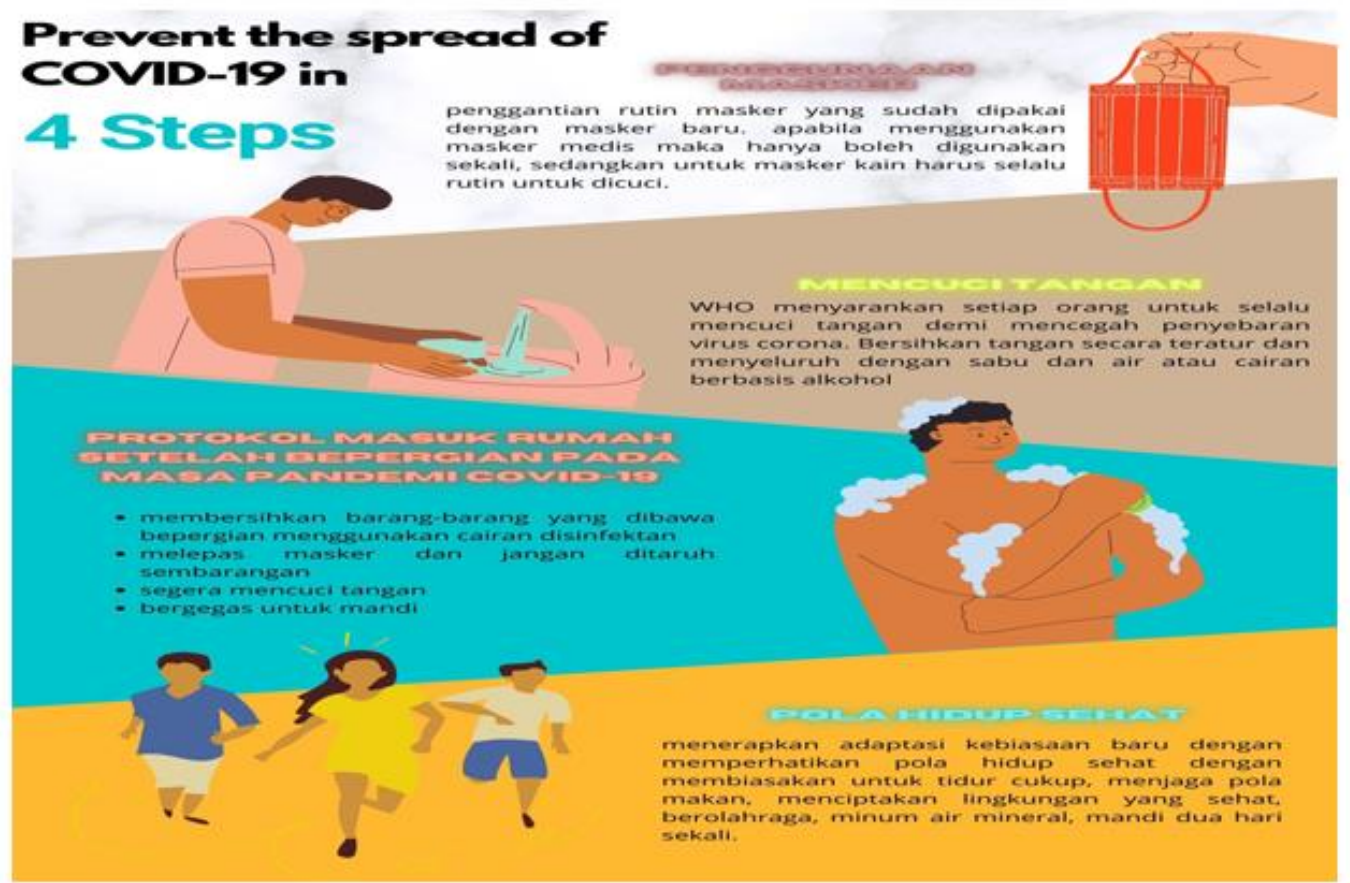

Gambar 2. E-Poster Prevent the Spread of Covid-19 
dan proteksi diri di lingkungan perumahan pada era new normal. Adapun sasaran dalam kegiatan ini yaitu:

a. Masyarakat di lingkungan RW 015 Perumahan Cijati Asri kelurahan Jayawaras, Kecamatan Tarogong Kidul Kabupaten Garut.

b. Anggota Karang Taruna di lingkungan Perumahan Prima Lingkar Asri.

c. Masyarakat di lingkungan Margahayu Raya Barat Kelurahan Sekejati Kecamatan Buah Batu RW 007 RT 003.

d. Anggota Karang Taruna di lingkungan Margahayu Raya Barat Kelurahan Sekejati Kecamatan Buah Batu RW 008.

e. Ibu ibu pengajian di lingkungan Komplek Perumahan Bekasi Timur Permai (BTP).

f. Ikatan Remaja Masjid Gegesik Cirebon.
Pihak-pihak yang terlibat dalam kegiatan ini yaitu:

a. Ir. Erwin Rinaldi, M.Sc sebagai narasumber webinar.

b. dr. Noor Anita Rahmalia sebagai narasumber webinar.

c. Masyarakat di lingkungan Perumahan Cijati Asri sebagai peserta webinar.

d. Anggota Karang Taruna di lingkungan Perumahan Prima Lingkar Asri sebagai peserta webinar.

e. Masyarakat di lingkungan Margahayu Raya Barat Kelurahan Sekejati Kecamatan Buah Batu RW 007 RT 003 sebagai peserta webinar.

f. Anggota Karang Taruna di lingkungan Margahayu Raya Barat Kelurahan Sekejati Kecamatan Buah Batu RW 008 sebagai peserta webinar.

g. Ibu-ibu pengajian di lingkungan Komplek Perumahan Bekasi Timur Permai (BTP) sebagai peserta webinar.

h. Ikatan Remaja Masjid Gegesik Cirebon sebagai peserta.

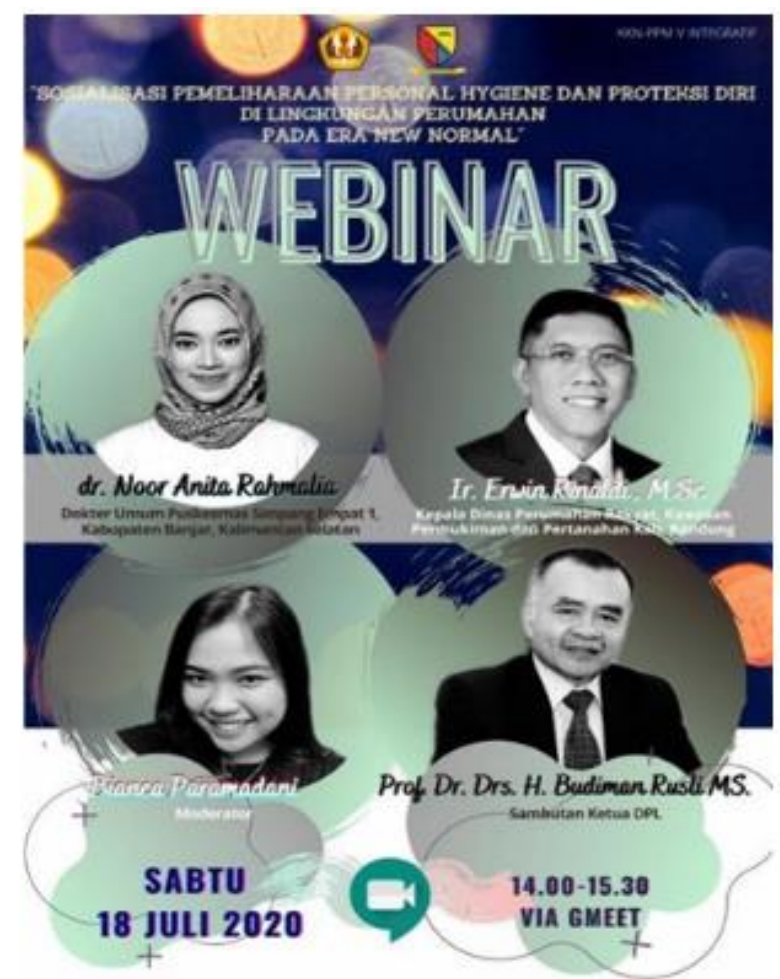

Gambar 3: e-Poster Webinar Pemeliharaan Personal Hygiene dan Proteksi Diri di Lingkungan Perumahan pada Era New Normal 
Pada webinar ini dijelaskan mengenai Perilaku Hidup Bersih dan Sehat (PHBS) selama masa pandemi Covid-19. Seperti diketahui, bahwa PHBS ini bertujuan untuk meningkatkan kualitas kesehatan individu dengan cara menjaga kebersihan diri dan lingkungan (personal hygiene). Tapi apakah kalian tahu tentang personal hygiene? Apa fungsinya? Dan apa saja faktor yang mempengaruhinya? Dalam bahasa Yunani, personal artinya perorangan dan hygiene berarti sehat. Menurut Potter \& Perry (2005), didefinisikan sebagai tindakan memelihara kebersihan dan kesehatan seseorang untuk kesejahteraan fisik dan psikis. Dengan menerapkannya, derajat kesehatannya akan meningkat, mencegah berbagai penyakit, meningkatkan kepercayaan diri dan menciptakan keindahan.

Namun, dalam penerapannya dipengaruhi oleh beberapa faktor, yaitu budaya, nilai sosial pada individu atau keluarga, pengetahuan terhadap perawatan diri, dan persepsi terhadap perawatan diri. Sedangkan menurut Potter \& Perry (2005), ada 7 faktor yang mempengaruhi seseorang untuk melakukan personal hygiene, antara lain:

1. Citra Tubuh, penampilan fisik seseorang adalah konsep subjektif dari citra tubuh. Citra tubuh mempengaruhi cara seseorang mempertahankan hygiene. Adanya perubahan fisik yang disebabkan oleh pembedahan ataupun penyakit, makan dibutuhkan usaha yang lebih untuk tetap mempertahankan hygiene.

2. Praktik Sosial, kelompok-kelompok sosial dalam pergaulan seseorang dapat sangat memengaruhi hygiene. Saat usia anak-anak, praktik hygiene didapatkan dari orang tua. Kebiasaan hidup di rumah, kebersihan lingkungan rumah, dan bagaimana anak diajarkan cara merawat diri. Seiring dengan bertambahnya usia, pergaulan di sekolah akan merubah cara praktik personal hygiene.
3. Status Sosial Ekonomi, pendapatan seseorang juga menjadi faktor yang sangat memengaruhi hygiene. Kemampuan seseorang untuk membeli peralatan dan bahan-bahan untuk merawat kebersihan diri dan lingkungan.

4. Pengetahuan, saat ini tidak sedikit seseorang yang tidak paham mengenai pentingnya hygiene bagi kesehatan. Oleh karena itu, faktor pengetahuan juga mempengaruhi walaupun pengetahuan itu sendiri tidak cukup untuk memotivasi seseorang untuk menerapkan personal hygiene dalam dirinya.

5. Kebudayaan, kebudayaan mempengaruhi personal hygiene karena cara yang diterapkan di satu daerah dan daerah lainnya akan berbeda. Penggunaan air untuk membersihkan diri setelah dari jamban adalah budaya yang ada di Indonesia. Sedangkan, untuk di negara-negara luar, seperti Jepang, China, dan Korea, cukup menggunakan tisu saja.

6. Pilihan Pribadi, setiap individu pada dasarnya punya caranya sendiri untuk melakukan perawatan terhadap dirinya, kapan waktu yang tepat, dan dengan apa perawatan diri itu dilakukan.

7. Kondisi Fisik, pada saat sakit, terutama sakit keras, tentu kondisi fisik akan menurun, sehingga kemampuan untuk merawat diri pun berkurang. Perlu bantuan orang lain untuk merawat diri.

Ketujuh faktor tersebut sangat memengaruhi hygiene seseorang. Pada masa pandemi seperti ini, sangat penting jika pemerintah mengampanyekan mengenai personal hygiene dan self-awareness. Kedua hal tersebut adalah hal yang paling dasar yang dapat dilakukan untuk memutus penyebaran virus corona. 


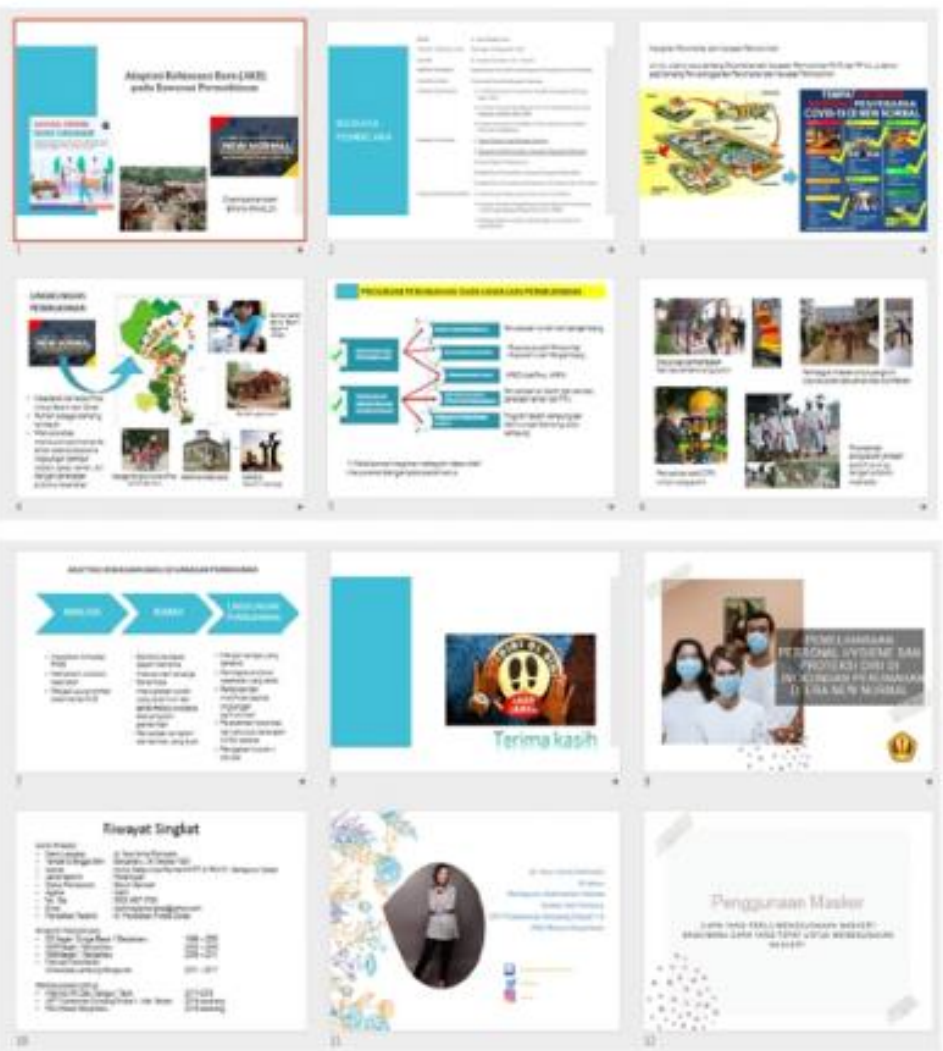

Gambar 4. Power Point Materi Webinar Pemeliharaan Personal hygiene dan Proteksi Diri di Lingkungan Perumahan pada Era New Normal

\section{Evaluasi}

Setelah dilaksanakan kegiatan Webinar mengenai "Pemeliharaan Personal hygiene dan Proteksi Diri di Lingkungan Perumahan pada mengundang narasumber secara langsung dengan tetap menggunakan protokol kesehatan.

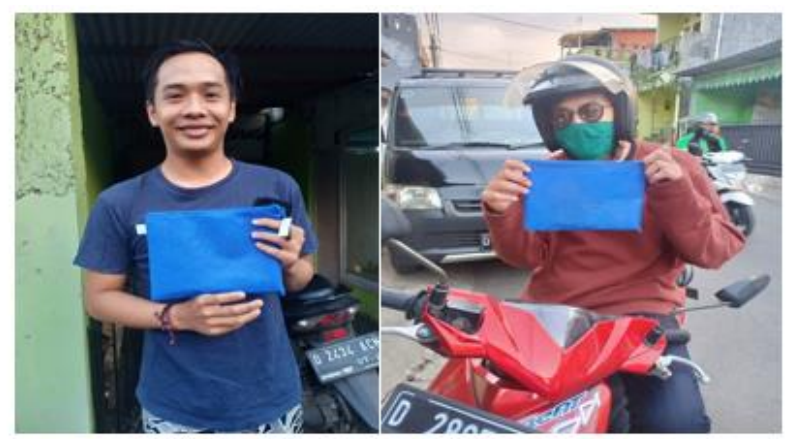

Gambar 5. Pemberian Goody Bag bagi Peserta Webinar di Karang Taruna

Era New Normal" mampu memberikan sedikit pengetahuan kepada masyarakat yang dijadikan subjek pengabdian untuk lebih mengetahui dan memahami mengenai proteksi diri dan personal hygiene di lingkungan perumahan. Setelah kegiatan itu, sudah mulai tumbuh kesadaran pada masyarakat walaupun masih harus kembali ditingkatkan. Sebagai tindak lanjutnya, diperlukan edukasi-edukasi yang rutin seperti webinar atau edukasi dengan

\section{KESIMPULAN}

Pelaksanaan Pengabdian Pada Masyarakat (PPM) berjalan dengan baik. Program yang telah dilaksanakan yakni melakukan kegiatan webinar dengan tema "Sosialisasi Pemeliharaan Personal hygiene dan Proteksi Diri di Lingkungan Perumahan pada Era New Normal". Partisipasi dan dukungan masyarakat cukup baik, di mana masyarakat 
turut aktif dalam pelaksanaan program sehingga masyarakat dapat mengambil manfaat yang lebih maksimal.

Walaupun program pengabdian berjalan dengan baik, namun masih memiliki beberapa kendala dan hambatan dalam melaksanakan program tersebut, seperti adanya kendala koneksi saat melakukan webinar secara online, persiapan yang kurang ketika program dilaksanakan, dan masih sulitnya mengumpulkan masyarakat untuk ikut berpartisipasi dalam program webinar. Adanya kegiatan pengabdian ini diharapkan dapat memberikan banyak manfaat bagi mahasiswa $\mathrm{KKN}$, pembimbing dan masyarakat yang ikut berpartisipasi dalam mengikuti program ini.

\section{REKOMENDASI}

Setelah program webinar ini berakhir, diharapkan masyarakat dapat menerapkan materi yang telah disampaikan dan memperluas lagi pengetahuan yang telah diberikan dari sumber-sumber yang terpercaya, sehingga didapatkan hasil yang lebih optimal.

\section{UCAPAN TERIMA KASIH}

Terima kasih yang sebesar-besarnya kepada pihak Universitas Padjadjaran atas bantuan dana PPM tahun anggaran 2020. Terima kasih juga kepada tim mahasiswa Kuliah Kerja Nyata (KKN) Virtual Universitas Padjadjaran Tahun 2020 yaitu: Bianca Paramadani, Miftahul Jannah, Pramesti Yustina Wardhani, Salsabila Aini, Yoga Malik Pratama dan Yunisah.

\section{DAFTAR PUSTAKA}

Departemen Kesehatan RI. (2010). Pedoman Program Perilaku Hidup Bersih dan Sehat. Jakarta: Departemen Kesehatan RI.

Lawrenche, F., Wulandari, N., Ramadhan, N., Rahayu, F., Bakhtiar, M. A., \& Nurrachmawati, A. (2020). Pemberdayaan Masyarakat Dimasa Pandemi Covid-19 Pada Ikatan Remaja Masjid RT.04 Loa Kulu. Kumawula: Jurnal Pengabdian Kepada Masyarakat, $3(3)$, 429-434. https://doi.org/10.24198/kumawula.v3i3. 28007

Potter, P., \& Perry, A. (2005). Fundamental Keperawatan: Konsep, Proses dan Praktik (4th ed.). Jakarta: ECG.

Saputra, L. (2013). Panduan Praktik Keperawatan Klinis. Padang: Binarupa Aksara.

Saryono. (2010). Catatan Kuliah Kebutuhan Dasar Manusia. Yogyakarta: Nuha Medika.

Satyarini, R., Pratikna, R. N., Mulia, F., \& Dewi, V. I. (2020). HYGIENE SANITASI MAKANAN JAJANAN KANTIN SEBUAH PERGURUAN TINGGI SWASTA $X$ DI BANDUNG UNTUK MENINGKATKAN KESEHATAN LINGKUNGAN. Kumawula: Jurnal Pengabdian Kepada Masyarakat, 3(3), 375-386. https://doi.org/https://doi.org/10.24198/k umawula.v3i3.25583

Sudarto. (1996). Penyakit-Penyakit Infeksi di Indonesia. Jakarta: Widya Medika.

Tarwoto, \& Wartonah. (2010). Kebutuhan Dasar Manusia dan Proses Keperawatan. Jakarta: Salemba Medika. 